\title{
Kurumsal İmaj Penceresinden Fenerbahçe Spor Kulübü'nün Mesut Özil Transferi
}

\section{Mehmet Ali HOROZOĞLU' \\ Selçuk Bora ÇAVUŞOĞLU ${ }^{2}$}

${ }^{1}$ Öğr. Gör., Karamanoğlu Mehmetbey Üniversitesi Sosyal Bilimler Meslek Yüksekokulu, Karaman, Türkiye, mahorozoglu@kmu.edu.tr

${ }^{2}$ Doç. Dr., İstanbul Üniversitesi Cerrahpaşa Spor Bilimleri Fakültesi, İstanbul, Türkiye, selcukbora.cavusogluiuc@edu.tr

\section{Özet}

$\mathrm{Bu}$ araştırmanın amacı Fenerbahçe spor kulübünün 2021 yılında yapmış olduğu ve dünya çapında yadsınamaz bir etki yaratan Mesut Özil Transferini Kurumsal İmaj çerçevesinden incelemektir. Kurumsal imaj, firmanın kendisi için önemli olan çeşitli izleyiciler nezdindeki itibarıdır. Kurumsal imaj kavramı günümüz dünyasında çok sık karşılaşılan ve gerek kurum gerekse şirketler tarafindan merkezi önem noktasında bulunan bir kavramdır. Son yıllarda kurumsal imaj kavramın öneminin artması ve medya boyutunun kurumsal imaj ile iç içe hareket etmesi ve bunun yanı sıra olarak spor kulüplerinin özellikle kurumsal imaj açısından transfer politikalarını araç olarak kullanması sebebi ile araştırmanın konusu kurumsal imaj çerçevesinde şekillendirilmiştir. Spor Kulüplerinin Kurumsal İmaj çerçevesinde transferleri araç olarak kullanmasının altında; kulüp gelirlerini arttırmanın yanı sıra kulüplerin tanınırlık seviyelerini arttırmak istemeleri yatmaktadır. Araştırmanın amacına etkili bir şekilde ulaşması ve bilim dünyasına bundan sonraki çalışmalarda ışık tutulabilmesi açısından araştırma deseni türlerinden derleme yöntemi uygulanmış ve teorik bir çözümleme yöntemi kullanılmıştır. Araştırmanın elde edilen bulguların analizleri sonucunda Fenerbahçe spor kulübünün Mesut Özil transferi sayesinde dünya borsalarındaki değer artı̧̧ının yanı sıra kulüp gelirleri, forma satış oranları, lisanslı ürün satış oranları ve son olarak sosyal medya hesaplarının takipçi sayılarında artış ve bu artışa bağlı olarak sosyal medya kanallarından elde edilen gelirlerin arttığı sonucuna varılmıştır.

Anahtar Kelimeler: Fenerbahçe, Mesut Özil, Kurumsal İmaj Year 5/ 2021, Volume-5, Issue-2 | www.ispecjournal.org 


\title{
Mesut Ozil Transfer of Fenerbahçe Sports Club from Corporate Image Window
}

\begin{abstract}
:
The purpose of this study is to examine the Mesut Özil Transfer, which Fenerbahçe sports club made in 2021 and has an undeniable impact worldwide, from the framework of its Corporate Image. Corporate image is the reputation of the firm with a variety of audiences that is important to it. The concept of corporate image is a concept that is frequently encountered in today's world and is of central importance by both institutions and companies. The subject of the research has been shaped within the framework of corporate image due to the increase in the importance of the concept of corporate image in recent years and the fact that the media dimension is intertwined with the corporate image, as well as sports clubs use transfer policies as a tool, especially in terms of corporate image. Under the Sports Clubs' use of transfers as a tool within the framework of Institutional Image; In addition to increasing club revenues, clubs are willing to increase their recognition level. In order to reach the purpose of the research effectively and to shed light on the scientific world in the future studies, the compilation method, one of the types of research designs, was applied and a theoretical analysis method was used. As a result of the analysis of the findings of the research, the increase in the value of Fenerbahçe sports club thanks to the transfer of Mesut Özil in the world stock markets, as well as club revenues, uniform sales rates, licensed product sales rates and finally the increase in the number of followers of social media accounts and the revenues from social media channels due to this increase. It is concluded that it has increased.
\end{abstract}

Key Words: Fenerbahce, Mesut Ozil, Corporate Image

\section{GíRiş}

Yapılan bu derleme çalışmasında elde edilen literatür taramaları sonucunda; daha önce ülkemizde bu konuya 1şık tutacak herhangi bir çalışma olmazken bazı kitap, dergi ve spor gazetelerinin köşe yazılarında bu konuları değinilmiş ve spor camiasının gözünü bu noktaya çevirmesi hedeflenmiştir. Kurumsal imaj kavramı son zamanlarda kurum ve kuruluşların olmazsa olmaz süreçleri arasında yer almaktadır. Kurumsal imaj kavramı bir kurum veya bir şirketin satış oranlarından tanınırlık seviyesine kadar her süreci etkileyen bir kavramdır.

Year 5/ 2021, Volume-5, Issue-2 | WWW.ispecjournal.org 
Özellikle son zamanlarda gelişen teknoloji ile birlikte kurumsal imaj süreçlerinin önem seviyesi giderek artarken spor kulüpleri kurumsal imajlarını etkili bir hale getirmek ve kurumsal imaj çerçevesinde kulübe ekonomik anlamda katkı sağlamak adına transfer süreçlerini sportif yönünün yanı sıra kurumsal imajlarını etkili hale getirmek adına yaptıkları görülmektedir. Bu araştırmanın amacı bu bağlamda Fenerbahçe Spor Kulübünün Mesut Özil Transferini Kurumsal İmaj Kavramı çerçevesinde değerlendirmektir.

Araştırmamızın bilim dünyasına 1şık tutması adına incelenen her kaynak titizlikle incelenmiş olup araştırma çerçevesinde verilen satış rakamları, borsa hisse değerleri ve lisanlı ürün satış oranları Fenerbahçe Spor Kulübü A.Ş'den resmi olarak alınmış ve aynı zamanda dünya çapında önemli bir yere sahip olan medya kuruluşlarından faydalanılmıştır. Araştırmamızın sonucunda ise Fenerbahçe Spor Kulübünün Mesut Özil transferinin sportif yönünün yanı sıra Fenerbahçe Spor Kulübünün Kurumsal İmajının gelişmesine merkezi önem noktasına sahip katkıda bulunduğu görülmektedir. Bu transferin bundan sonraki transferlere 1şık tutacağ1 düşünülürken spor sektörünün kurumsal imajı iyileştirip geliştirmede vazgeçilmez ve gözden gelinemeyecek kadar önemli bir sektör olduğu düşünülmektedir.

\section{1. İmaj Kavramı}

Günümüzde imaj kavramı, enformasyon devrinin bir yansıması olarak, üzerinde çok durulan ve daima tartışmaya açık bir kavram olarak karşımıza çıkmaktadır. Bireyler, hizmetler, ürünler, olaylar, fikirler, kurumlar, uluslar, ülkeler ve devletler hakkında edinilmiş olan algı, izlenim, genel kanı ve beyinde dizayn edilen kurguya imaj denilmektedir. Basit bir tabir ile imaj, kısa veya uzun vadede bir bireylerin, kurumların, objelerin veya ülkelerin sahip olduğu genel değerleriyle ilgili ikonların algılanış biçimidir (Gültekin, 2005: 127). İmaj, karşıdakilerin durumlarını yansıttığı kadar imaj yapıcının kendi alımlama durumlarını da yansıtmaktadır. Ayrıca imaj kavramı, gerçeğin tam bir ifadesi olmadığı gibi, alımlayıcı tarafın, bu doğrultuda genel bir kanıya varanın algısına göre de gerçeklikten uzaklaşabilir.

İmaj kavramını özetleyecek olduğumuzda, kurum içerisinde çalışan bireylerin kuruma karşı olumlu izlenimlerinin kurumların amaçladığı hedef kitlenin izlenimlerini kendileri açısından olumlu yönde şekillendirmede rolünün önemli olduğu söylenebilir. Çalışanlar tarafından ortaya konulan etkili ve yaratıcı bir imaj beğenebilirlik ve güvenilirlik algısını seviyesini de dış paydaşların huzurunda kurum lehine şekillendirebilir. Ayrıca imaj kavramı, çalışanların fiziki görünümleri ve kişisel bakımları, eğitim düzeyi, iletişim becerisi, beden dilleri, yaratıcı 
çözümler ortaya çıkartması ürün ve hizmetleri satın alacak paydaşların tercih sebeplerinde de büyük bir paya sahiptir (Gökçe Ateş Ç.,2016).

İmaj kavramı son dönemlerde futbol kulüpleri açısından da vazgeçilmez bir kavram haline gelmiştir. Kulüplerin transfer politikaları, sponsorluk anlaşmaları vb. gibi süreçleri imaj kavramının bileşenleri çerçevesinde değerlendirilmekte ve imaj kavramının bileşenleri doğrultusunda şekillenmektedir. Özellikle gelişen teknoloji dünyasında futbol kulüplerinin sosyal medya platformlarında da imaj kavramının bileşenleri üzerinden yol haritaları çizilmekte ve bu doğrultuda süreçler planlanmaktadır.

\section{Kurumsal İmaj Kavramı}

Uluslararası platformda "Corporate İmage" olarak tanımlanan kurumsal imaj kavramı geçmişten günümüze önem seviyesi giderek artan ve kurum veya kuruluşların vazgeçilmezi olarak ön plana çıkan bir kavram olarak sivrilmiştir. Kurumsal imaj kavramı çerçevesinde literatür incelendiğinde farklı kesimlerden olan araştırmacılar tarafindan ve alana hâkim uzmanlar tarafında birçok tanımlama yapıldı̆̆ı görülmektedir.

Karşımıza çıkan kurumsal imajın ilk tanımına baktığımız zaman bireysel algıların dışında grupların algılarına yer verilir. Bu 1şıkta bireylerin kuruluşu nasıl algıladığ 1 değil grupların kuruluşu nasıl algıladığına yer verilirken, ona yönelik tecrübe, değerler bütünü, inanç seviyesi, yargıları, hissiyatları, bilgi ve kanaatlerini de içerdiği, gruplar üzerinde oluşan pozitif ya da negatif fikirlerin bütünü olarak ortaya çıktığı belirtilmektedir (Çetin, Tekiner, 2013: 423; Bolat, 2011: 109).Bu tanımlama doğrultusunda kurumsal imaj, gurupların algılama seviyelerinin sonucunda ortaya çıkan, tanımladıkları ve hatırladıkları ile ilişkilendirebildikleri fikirlerin bütünü olarak ortaya çıkmaktadır.

Literatürde yer alan farklı bir kurumsal imaj kavramını incelediğimizde kurumsal imaj kavramına dair önümüze çıkan farklı bir tanımlamada kurumsal imaj kavramı, "müşteri olarak tanımlanan bireylerin algılarında kurum ya da kuruluş ile ilgili meydana gelen tecrübelerin, inanç seviyelerinin, duygu durumlarının, bilgilerin ve uyaranların bir bütünü” (Çetin, Tekiner, 2013: 419) olarak tanımlanmaktadır. Bu tanımlama 1şı̆̆ında kurumsal imaj kavramını örnek ile destek verecek olursak, kurumsal imaj ile ilgili alanda söz sahibi olan ve kurumsal imaj çerçevesinde gelişmeleri dikkate alan Andreassen ve Lindestad, zaman içerisinde satın alma düzeyi ve tüketim tecrübelerinin yanı sıra birikiminin bir fişlevi olarak kurumsal imaj kavramının tanımlanabileceğini ortaya koymuşturlar (Panagopoulos ve Stergıou, 2007: 88).

Year 5/ 2021, Volume-5, Issue-2 | WWW.ispecjournal.org 
Kurumsal imaj kavramı çerçevesinde yapılan tanımlar incelendiğinde bir takım farklı özelliklerin yer aldığ 1 , bu özelliklerin kurumsal imaj kavramanı idrak edebilmesinde son derece önemli değerler bütünlüğü oluşturduğu ortaya çıkmaktadır. Ortay çıkan bu tanımlamalar 1şığında kurumsal imaj kavramının somut bir etken olmamasının yanı sıra kurumsal imaj kavramının rasyonel ve duygusal bağlılıklarla sivrildiği ortaya çıkmaktadır. Bunun yanı sıra farklı kurumlara ilişkin algı seviyelerinin olası kitlenin kalıcı belleğinde varlığının yer edinmiş olması ve kurumsal imajın kurum ve kuruluşun hedef kitlesinin bir bölümünde değil tümünde ortaya çıkan bir etken olmasıdır (Alkibay ve Ayar, 2013: 30).

Özellikle Bilgi Teknolojilerinin görmezden gelinemez bir gerçek olduğu günümüz dünyasında bu görüntülere erişim sağlayabilmek hızlı ve kolaydır. Bahsi geçen bu görüntülerin kurum ve kuruluşların kurumsal imaj kavramının etkili bir biçimde yürütmede ve kurumsal imaj penceresinden hedeflenen verilere ulaşmada önemli bir role sahip olduğu bilinmektedir. Tüketiciler nezdinde bu görüntüler olumlu yönde bir mesaj barındırıyor ve akılda kalıcılığı etkili bir şekilde sağl1yor ise kurum ve kuruluşlar kurumsal imaj sürecini iyi yönettiğinin kanıtıdır ve bu kanıtlar kurum ve kuruluşlara önemli katkılar sağlamaktadır (Bolat, 2011: 109).

Gelişen bilişim teknolojileri dünyasında kurumsal imaj kavramının kalite ile gözle görülebilir bir ilişkisin olduğu yapılan tanımlamalardan anlaşılmaktadır. Bu hususta kurum ve kuruluşlar çerçevesinde yer alan spor kulüplerinin kalitelerini arttırmak ve hayran kitlelerini ulaşmada kurumsal imaj kavramının yerinin merkezi bir önem noktasına sahip olduğu aşikardır. $\mathrm{Bu}$ doğrultuda kalitelerini arttırmak ve etkili bir biçimde kar elde etmek isteyen spor kulüpleri kurumsal imaj kavramını attığım her adımda hissetmesi ve kullanması gerekmektedir.

\section{Mesut Özil ve Kariyeri}

$\mathrm{Bu}$ bölümde Çalışmamızın ana unsurlarında bir tanesi olan Mesut Özil'in kariyer geçmişi anlatılmaktadır.15 Ekim 1988 yılında Almanya'nın Gelsenkirchen kasabasında dünyaya gelen Mesut Özil aslen Türkiyelidir. Zonguldaklı türk asıllı bir ailenin çocuğu olan Mesut Özil Futbol kariyerine ilk olarak Almanya'nın DJK Westfalia 04 Gelsenkirchen futbol takımında başlamıştır. Bu yerel takımda 3 yıl forma giydikten sonra birer yıl süreyle DJK TEUTONİA Schalke Nord ve DJK Falke Gelsenkirchen takımlarında kariyerine devam etmiştir. Kariyerine devem ederken babası tarafından futbolunun gelişmesi ve futbolun eğitimini alması açısından Rot-Weiss Essen altyapısını yazdırıldı. Bu dönemlerde Mesut Özil'e birçok 
takımdan profesyonel tekliflerde bulunulsa da Mesut Özil'in babası olan Mustafa Özil gelen tekliflerin hiçbirini kabul etmeyerek oğlunu alt yapıda tutmaya devam etmiştir.2001 yılında Rot-Weiss Essen tarafında profesyonel sözleşme teklifi gelince Mustafa Özil bu sözleşmeyi kabul etmemiştir ve Mesut Özil Schalke 04 takımının yolunu tutmuştur. Burada futbol oynamaya başladıktan sonra dönemin Schalke 04 kulüp başkanı Gerhard rehberg Mesut Özil'in Fenerbahçe ve Galatasaray gibi iki büyük Türk kulübüne önerilmiş fkat kulüplerden denemeye bile gerek cevabının alınmasının ardından Mesut Özil kariyerine Schalke 04'te devam etmiştir.

2006-2008 yılları arasında Schalke 04 formasını giyen Mesut Özil burada çeşitli başarılara imza atıp kendine alman futbol camiasına kanitlayarak 2008 y1lında Almanya bundesliga takımlarından köklü bir geçmişe sahip olan Werder Bremen ile 4.3 Milyon dolarlık bir sözleşme imzalayarak Schalke 04 kariyerine son noktayı koymuştur.2008-2010 y1lları arasın Werder Bremen ile çıktığı 71 Lig maçında 13 gol atan Mesut Özil 2 yıl boyuna orta saha ve oyun kurucu mevkiinde oynadı. Bu yıllarda A Milli takıma çıkmayı başaran Mesut Özil kendini Alman Futbol Camiasına kanıtlayarak ilk resmi milli maçını 11 Şubat 2009 da Norveç Milli Takımına karşı oynamıştır. 2009 yılından hemen sonra 2010 yılında gerçekleşen Dünya

Kupasında Alman Milli takım formasını giyen Mesut Özil takımının dünya üçüncüsü olmasında önemli katkı sağlayarak turnuvada altın Top ödülüne aday gösterilerek bu başarıyı perçinlemiştir. Dünya kupasının hemen ardından köklü kulüplerin transfer için sıraya girdiği Mesut Özil transfer dönemin İspanya'nın köklü kulüplerinden olan Real Madrid ile yıllık 5 Milyon Avroluk bir teklif ile kendisini 6 yıllığına Real Madrid'e bağlayan sözleşmeyi imzalamıştır. Burada taraftarlar tarafindan Mesut Özil'in göçmen olması sebebi ile Mesut Özil'e Alman Zidane lakabı veriliyor. Real Madrid ile ilk resmi maçına3 Ekim 2010 yılında çıkan Mesut Özil Deportivo La Corunaya karşı ilk 11 de çıktığı karşılaşmada Real Madrid forması ile ilk resmi golünü atmıştır. Real Madri kariyerine toplamda 159 karşılaşmaya çıkan Mesut Özil toplam da 27 gol ve 82 asist yaparak takımına katkıda bulunmuştur.

Real Madrid kariyerinden sonra 2013 y1lında İngileter Premier Ligin köklü ekiplerinden olan Arsenal futbol Kulübü ile anlaşarak İngiltere Kariyerini başlatan Mesut Özil Burada ilk karşılaşmasına 14 Eylül 2013'te Sunderland takımına karşı oynamış ve bu karşılaşmada bir asist yapmıştır. Başarılı grafiği sebebi ile Arsenal ile 2018 yılının hemen başında Sözleşmesini 3 yıl uzatarak Haftalık kazancını 350 bin paunda çıkartmıştır. 2019 yılında Arsenal kulübü ile araların da problemler yaşayan Mesut Özil Uzun bir süre takım ile iletişim

Year 5/ 2021, Volume-5, Issue-2 | WWW.ispecjournal.org 
konusunda problemle yaşamıştır. Sorulan her transfer sorusuna 2021 y1lına kadar Arsenal de kalacağını belirten Mesut Özil sportif açından maç eksikleri ile gündeme gelmiştir. Andemi sürecinin araya girmesinin ardından takımla kopma noktasına gelen Mesut Özil Kulüp tarafından aldığı ücretlerde indirim yapılmasını teklifini kabul etmemiş ve kulüp ile olan ilişkilerini ileri derecede sorunlu hale gelmesine sebep olmuştur. Daha sonra yapılan açıklamada Mesut Özil tarafına süreçlerin detaylı bir şekilde anlatılmadığı bu yüzde iletişim kopukluğunun olduğunu detaylı bir şekilde anlatılsa indirime gitme taraftarı olacağını belirten Mesut Özil'in 2020 sonlarında ismi artık Fenerbahçe Spor Kulübü ile anılmaya başlamıştır.

Nitekim 24 Ocak 2021 tarihinde Mesut Özil kariyerinde ilk Türk Takımına Transferini gerçekleştirmiştir. Fenerbahçe ile 3,5yıllık sözleşme imzalayan Fenerbahçe Spor kulübü hem sportif hem de kurumsal imaj açısından Mesut Özil transferinde gelir ve başarı elde etmeyi planlayarak bu transferi yapmıştır. Mesut Özil'in başarıları arasında; Almanya Kupası, Avrupa 21 Yaş Altı Şampiyonluğu, Almanya Kral Kupası, La Liga Şampiyonluğu, İspanya Süper Kupa, FA cup, 2014 Dünya Kupası, İngiletere Süper Kupası yer almaktadır.

\section{Mesut Özil'in Fenerbahçe'ye Transferinin Dış Basında Yansımaları}

Fenerbahçe Spor Kulübünün Mesut Özil transferi sonrasında gerek dünya basını gerekse de yurt basınında transfer konulu birden çok haber yayınlandı. Bu haberlerin Fenerbahçe'nin tanınırlık seviyesine ve tanınırlığa paralel olarak kurumsal imajını geliştirmesine katkıda bulunduğu düşünülürken bu başlık altında dış basın da yer alan transfer haberlerini işleyeceğiz.

İlk olarak Fenerbahçe spor kulübünün Mesut Özil'i İstanbul'a getirmesini içeren transfer haberini görsel ekleyerek sosyal medya kanallarından paylaştı ve bunun ilk etkisini dünya çapında 14 Milyon takipçisi olan FIFA'nın resmi twitter hesabı paylaştı. Böylelikle Fenerbahçe ilk olarak transferini dünya üzerinde bu paylaşım aracılığı ile dünya basınına duyurmuş oldu. 


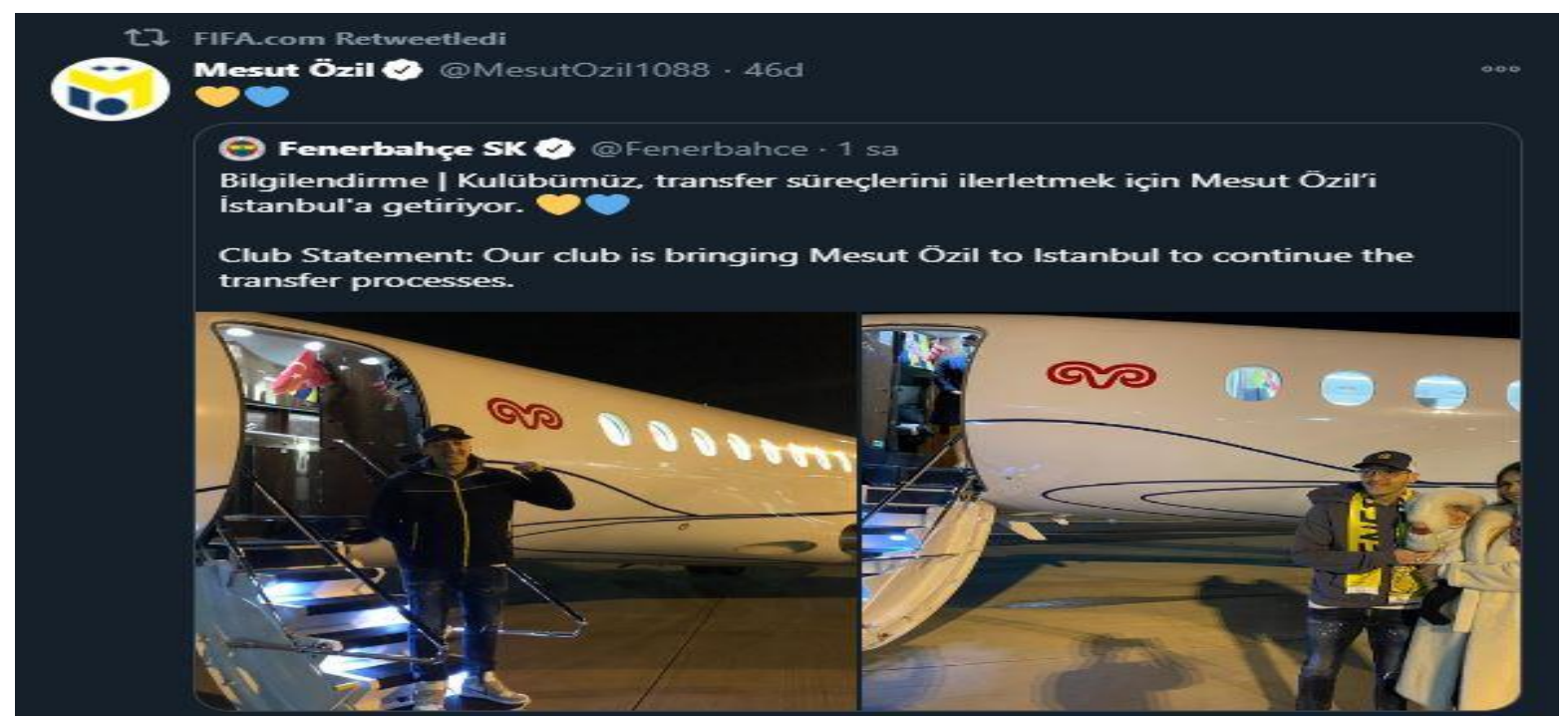

(www.turkish.aawsat.com,02.04.2021)

$\mathrm{Bu}$ twett atıldıktan sonra dünya basınının önemli ve etkili medya kuruluşları Fenerbahçe spor Kulübünün Mesut Özil transferini haberleştirerek takipçilerine duyurmaya başladı. Almanya'nın önde gelen ve günlük tirajı basılı gazete bazında 1,5 Milyon dijital ortamda ise günlük 400.000 kişiye(https://www.eurotopics.net) ulaşan Bild gazetesi Mesut Özil'in Fenerbahçe spor Kulübüne olan transferini hem gazetede hem de dijital ortamda bulunan haber sitesinde yer verdi. Gazete " Dünya Şampiyonu Fenerbahçe’ye Transferini Doğruladı" manşeti ile hafta boyunca Mesut Özil'in Fenerbahçe'ye transfer olacağının sinyalleri verilirken haber içerisinde ayrıca Mesut Özil'in Fenerbahçe Spor Kulübüne olan transferinden duyduğu memnuniyete de yer verilmiştir. Haber yayınlanması ile Fenerbahçe Spor Kulübü adından dünya basınında bahsettirmeye başlamıştır (www.fotomaç.com.tr). Fenerbahçe spor Kulübü bu haber ile gazete tirajları ve haberin Bild gazetesinin sosyal medya hesapları üzerinden paylaşılması ile sadece bu haber ile uluslararası basın camiasında doğrudan 3,5 Milyon kişiye ulaşmıştır. 


\section{Das steckt hinter diesem 0zil- Tweet}

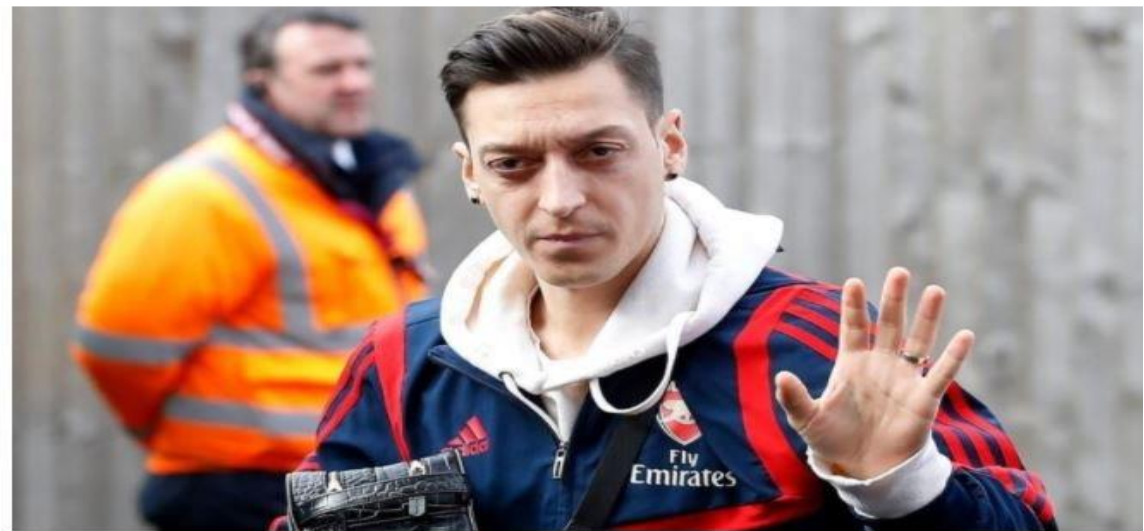

Ischüss Arsenal, hallo Istanbul! Mesut ōzils Wechsel zu Fenerbahce ist so gut wie durch

(https://www.fotomac.com.tr/galeri/fenerbahce/fenerbahcenin-mesut-ozil-transferi-dunya $\underline{\text { basininda/2) }}$

Fenerbahçe spor Kulübü'nün Mesut Özil transferi dünya basınında önemli ölçüde yer bulmuştur. Almanya'nın bir diğer önde gelen spor dergisi olan Kicker dergisi Mesut Özil'in transferini hafta içi baskısında yer vermiştir. Kicker dergisi Haftalık 2 adet olarak çıkmakta ve haftalı tirajı 500.000 bandında olan uluslararası bir spor dergisidir(https://tr.qaz.wiki/wiki/Kicker_sports_magazine). Kicker dergisinin haftalık 500.000 tirajının yanı sıra sosyal medya hesaplarında İnstagram 857 bin, İnstagram 31.000, Facebook 519.000 takipçi olmak üzere toplamda sosyal medya kanallarında 1 Milyon 400 bin aktif kullanıcıya sahip olan kicker dergisi bu haberi sosyal medya hesaplarından da paylaşmıştır. Doğal olarak yapılan haber ile birlikte Fenerbahçe Spor Kulübü adını uluslararası arenada 1 Milyon 400 bin kişiye duyurmuştur. 


\section{Özil bestätigt Wechsel zu Fenerbahce}

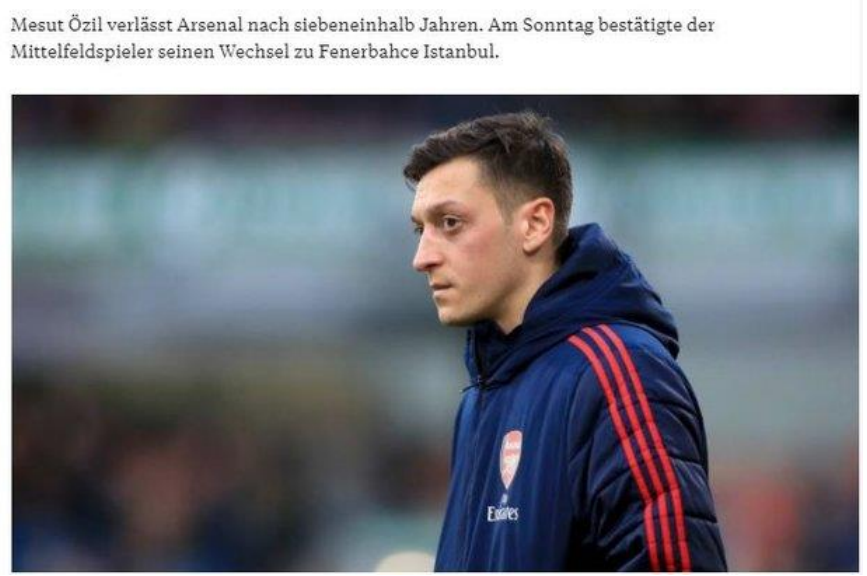

https://www.fotomac.com.tr/galeri/fenerbahce/fenerbahcenin-mesut-ozil-transferi-dunya-

\section{basininda/2)}

Dış basında transferin etkileri önemli ölçüde yankılanırken ve Fenerbahçe Spor kulübü açısından sadece bu transfer ile milyonlarca kişiye dünya çapında ulaşılmıştır. Bunun ışı̆̆ında kurumsal imaj çerçevesinde önemli katkılar doğurduğu ortaya çıkmaktadır.

Dünya basınında Mesut Özil transferine yer veren bir diğer önemli ve İngiltere'nin en önde gelen gazetelerinden olan 'The Sun' Mesut Özil transferini ' Türk Lokumu', başlığı ile yayınlayarak günlük tiraj açısından günlük 1.207.000 kişiye ulaşmıştır. Bu haber ile sadece gazete ile Fenerbahçe spor kulübü futbolun önde gelen ülkelerinden olan İngiltere gibi bir ülkede adından bahsettirmiştir. The Sun gazetesinin günlük tirajının yanı sıra sosyal medya hesaplarından bu haberi dijital ortamlarda paylaşması da kitleyi arttırmaktadır. The Sun gazetesinin sosyal medya hesaplarını incelediğimizde İnstagram;354.00 Facebook 3.3 Milyon ve son olarak Twitter 1 Milyon 850.000 kullanıcı olmak üzere toplamda aktif olarak 5 milyon 504.000 kullanıcıya sahip olduğunu görmekteyiz. Bu bilgiler 1şı̆̆ında Fenerbahçe Spor Kulübü Sosyal Medya kanalından yalnızca Mesut Özil transfer haberi ile uluslararası basın arenasında 5 milyon 504 bin kişiye ismini duyurmuştur ki buda kurumsal imaj çerçevesinden önemli bir rakamdır. 


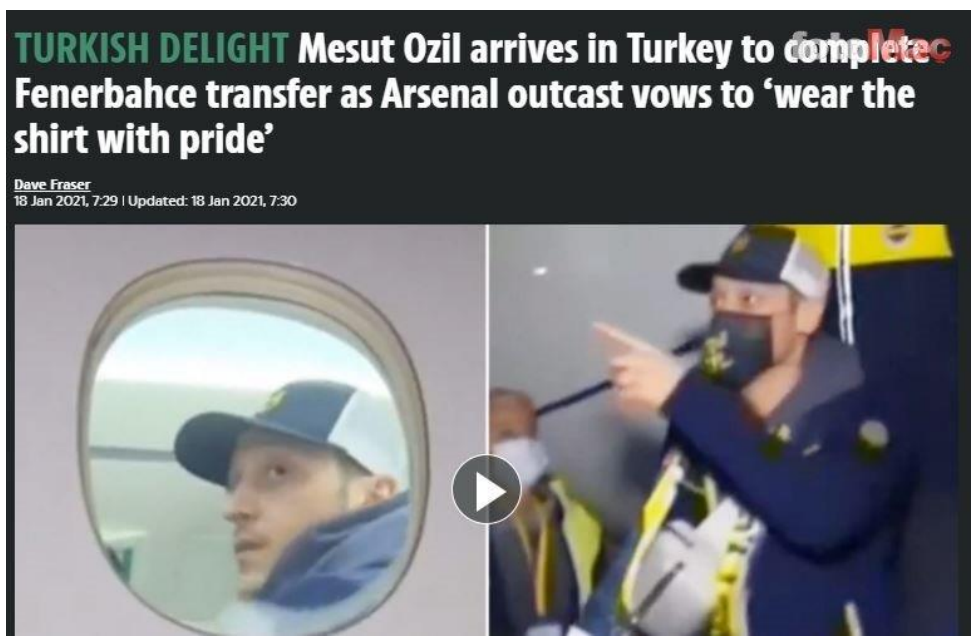

(https://www.fotomac.com.tr/galeri/fenerbahce/fenerbahcenin-mesut-ozil-transferi-dunyabasininda/7,5.04.2021).

Dünya basınında bir diğer haber ise dünya çapında okur kitlesi bulunan BBC Sport'dan geldi. BBC sport Mesut Özil’in Fenerbahçe Spor Kulübüne olan transferini dijital medya aracılığ ile duyurdu.BBC Sport haberin detayında ise Mesut Özil'in eski kulübünde olan huzursuzluğunun sona erdiğini ve artık yeni kulübüne doğru yol aldığının üzerinde durdu. Fenerbahçe spor kulübü bu transfer sayesinde dünya üzerinde etkili bir okur kitlesine sahip olan BBC Sport'un haber bültenlerinde yer alarak dünya çapında ismini duyurarak önemli bir kurumsal imaj sürecine imza attı.

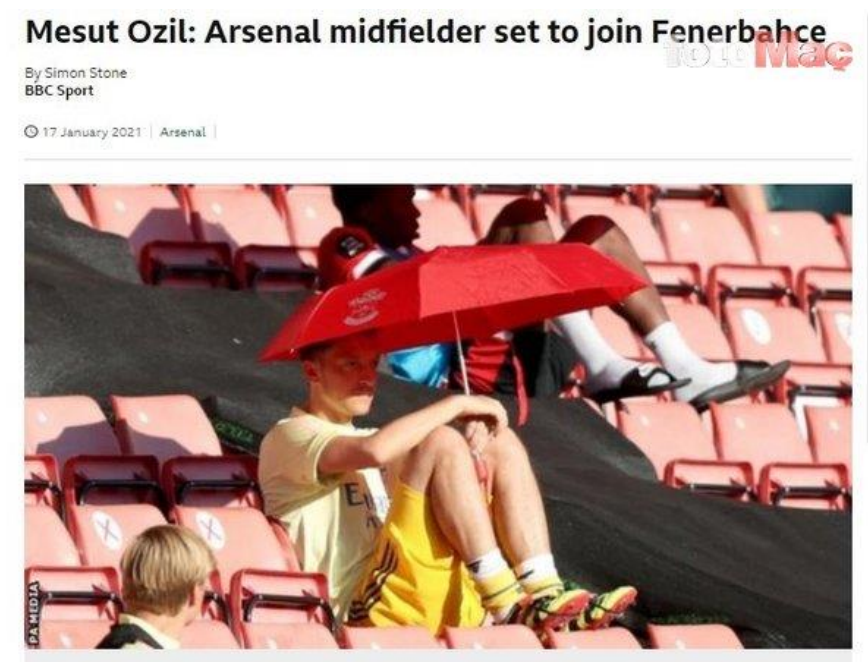

(https://www.fotomac.com.tr/galeri/fenerbahce/fenerbahcenin-mesut-ozil-transferi-dunyabasininda/7,5.04.2021).

Dünya basınında yer alana haberlerin yanı sıra Türkiye'de ve Yurt dışında birçok medya kuruluşu Mesut Özil'in Fenerbahçe Spor Kulübü'ne olan transferini canlı olarak yayınladı. İspanya'nın önde gelen spor gazetelerinden olan AS gazetesi Mesut Özil'in Fenerbahçe’ye Year 5/ 2021, Volume-5, Issue-2 | WWW.ispecjournal.org 
spor kulübüne olan transferini hem dijital medya kanallarında hem de gazetesinde yer verdi(www.ajanspor.com). Bunun yanı sıra Mesut Özil'in Fenerbahçe Spor Kulübü ile gerçekleşen imza törenini de AS TV'den canlı olarak yayınladı. Bu bilgiler ışığında Fenerbahçe Spor Kulübü bu transfer ile kurumsal imaj yönünde ne kadar doğru bir strateji geliştirdiği aşikardır.

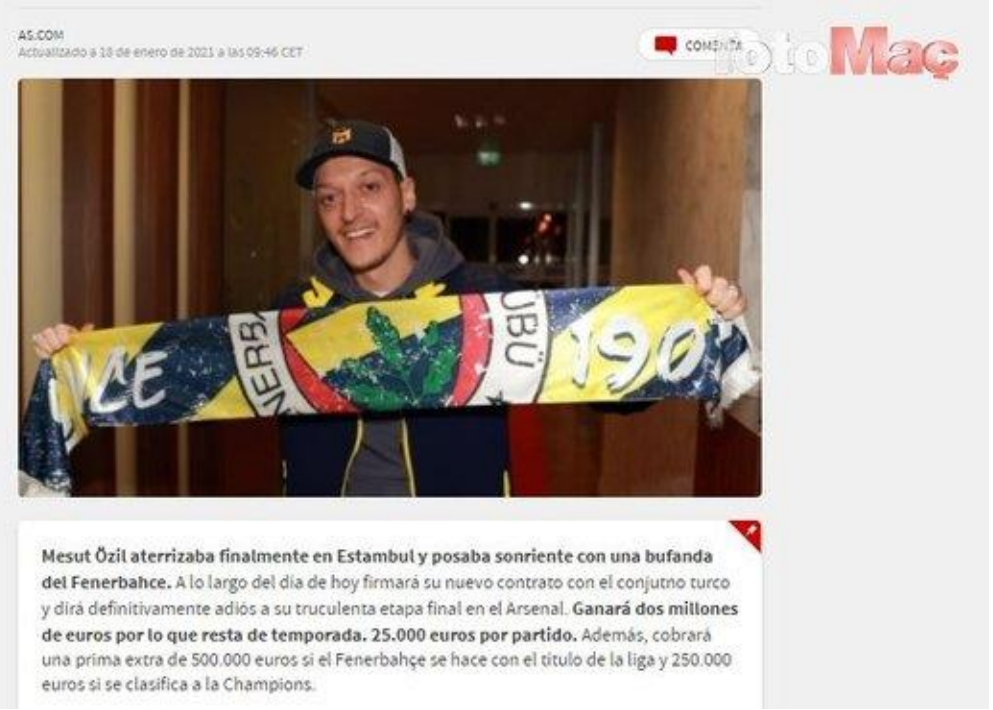

(https://www.fotomac.com.tr/galeri/fenerbahce/fenerbahcenin-mesut-ozil-transferi-dunyabasininda/7,5.04.2021).

\section{SONUÇ}

Araştırmamızda elde edilen sonuçlara göre; Fenerbahçe Spor Kulübünün Mesut Özil transferini duyurmasını ardından sadece sportif açıdan değil ekonomik açıdan da getirileri olmuştur. Özellikle Fenerbahçe Spor Kulübünün Borsadaki değerlerinin artışa geçtiği ve lisanslı ürünlerin satışında artış olduğu yapılan araştırma sonucunda elde edilen veriler arasındadır. Yapılan tarama sonuçları gösteriyor ki Mesut Özil Fenerbahçe Spor Kulübüne sadece sportif katkı değil ayrıca marka değerini arttırmasında da etkili olmuştur. Fenerbahçe Spor Kulübü transfer sürecini duyurur duyurmaz Borsadaki değerlerinde olumlu yönde hareketlenmeler gerçekleşmeye başlamıştır. Mesut Özil'in İstanbul'a geldiği hafta olan 18 Ocak günü Fenerbahçe Spor Kulübün hisse değerleri önceki haftaya göre günlük \%7 oranında bir artış ile başlamıştır. Fenerbahçe Spor Kulübü Mesut Özil'in İstanbul'a getirmesinden önceki hafta borsa değerleri haftayı \%2,70 artışla 41,90 puanla kapatmıştır. Mesut Özil transferinin hafta sonu sosyal medya hesaplarından duyurulması ve hafta başında Mesut Özil'in İstanbul'a getirilmesi ile birlikte Fenerbahçe Spor Kulübünün Haftalık Borsa değeri 
\%7 oranlık bir artışla haftaya geçen haftadan 2,90 puanlık artışla 45,10 puanla başlayarak hafta boyu bu yükselişi devam etmiştir. Uzman ekonomistlerin yorumları dikkate alındığında bu gelişme ara transfer döneminde spor kulüpleri açısından alışılagelmişin dışında bir artış olarak yorumlanmaktadır. Mesut Özil transferinden sonra artan hisse değerleri 2020 yılının eylül ayından itibaren \%50'lik bir artış performansı ile en yüksek seviyeye ulaşmıştır. Bu artışın alt yapısı incelendiğinde Mesut Özil'in tanınırlığı, dünya basınında yer alan haberlerin etkili olduğu sonucuna varılmıştır.

Fenerbahçe Spor Kulübünün Mesut Özil transferinin ekonomik etkisinin yanı sıra günümüz dünyasında kurumsal imaj çerçevesinde önemli bir role sahip olan sosyal medya penceresinden de etkili bir süreç işlediği araştırmada elde edilen bir diğer sonuçtur. Gelişen teknoloji dünyasında kurumların kurumsal imajlarını etkileyen ve kar elde etmesini sağlayan önemli etkenlerden bir tanesi sosyal medya platformlarıdır. Bu platformları etkili kullanan spor kulüpleri gelirlerini hatırı sayılır derecede arttırmaktadır. Araştırmamızda ulaştığımız sonuca göre Fenerbahçe Spor Kulübü Mesut Özil transferi sayesinde tüm sosyal medya platformlarında etkili bir süreç yöneterek kurumsal imajına katkıda bulunmuştur. Fenerbahçe Spor Kulübünün transfer ile attığı ilk tweet olan " gel gündüzle gece olalım” paylaşımı 218.000 kişi tarafından retweet edilirken aynı tweet 610.000 beğeni ve 61.000 yorum almıştır. $\mathrm{Bu}$ rakamlar Fenerbahçe Spor Kulübünün son 10 yılda sosyal medya platformu twitter'da ulaştığı en yüksek etkileşim oranıdır. Fenerbahçe Spor Kulübünün en fazla etkileşim aldığ paylaşım ise Mesut Özil'in Fenerbahçe Atkısı ile verdiği pozda almıştır. Bu fotoğraf toplamda twitter üzerinden 328.000 beğeni alarak kulübün twitter hesabının aldığı en yüksek beğeni oranıdır. Toplam olarak baktığımızda ise transfer haberinin dışında sadece iki gönderi ile Fenerbahçe Spor Kulubü'nün Twitter üzerinden yaptığı paylaşımlar 339.000 Retweet, 1 Milyon 390.000 Beğeni ve 80.000 yorum alarak Türkiye tarihinde daha önce bir spor kulübünün almadığı bir rakama ulaşarak kurumsal imajını sosyal medya üzerinden verimli kılmıştır. Bunun yanı sıra YouTube üzerinden toplamda transferinde etkisi ile 1 Milyon 950 Bin aboneye ulaşan Fenerbahçe SK kanalı transferden sonra kanalını ücretli hale getirerek abonelik ile üyelere içerik sunulmaya başlandı. Türk spor tarihinde ilk defa böyle bir uygulamaya giden Fenerbahçe Spor Kulübü ilk etapta buradan 4 Milyon 487 Bin TL kazanarak sosyal medya gelirlerini arttırmıştır.

Fenerbahçe Spor Kulübü’nün İnstagram hesabı verileri incelendiğinde Mesut Özil'in İngiltere'den çıkış yaptığı fotoğrafı 1 Milyon 250 Bin beğeni alırken Fenerbahçe atkısı ile 
verdiği pozda ise 1 Milyon 248.000 beğeni alarak İnstagram platformu açıldığından bugüne en yüksek beğeni rakamlarını alarak toplamda 2 Milyon 498.000 bin kişiye doğrudan ulaşarak bu transferi kurumsal imaj çerçevesinde sportif başarıdan önce kurumsal imaj açısından başarıyı yakalamıştır. Yine sosyal medya platformu olan twitter'dan yapılan ' gel gündüzle gece olalım tweete', dünyaca ünlü futbolcu Cristiano Ronaldo'nun Real Madrid'den Juvetus'a transferinin ilan edildiği tweete'de geçti. Cristiano Ronaldo'nun transfer paylaşımı 2018 yılında 24 saatte 535 bin beğeni alarak etkileşim rekoru kırmıştı. Fenerbahçe Spor Kulübünün Mesut Özil Transfer Paylaşımı ise toplamda 24 saatte 592 bin 100 kişi tarafından beğenildi. Bu paylaşım Cristiano Ronaldo’nun transfer paylaşımını geride bırakmanın yanı sıra Türk Spor Tarihinde etkileşimi en çok olan paylaşımdır ve bunu ilk olarak Fenerbahçe Spor Kulübü Gerçekleştirmiştir. Bu rakamlar ve rakamların sonuçları dikkate alındığında Fenerbahçe Spor kulübü sadece transfer yaparak kurumsal imajını güçlü hale getirmiştir ve dünya çapında adından söz ettirerek kurumsal değerini yükseltmiştir.

Araştırma verilerinin sonuçlarına göre ortaya çıkan bir diğer sonuç ise Fenerbahçe Spor Kulübünün Mesut Özil transferi sayesinde lisanslı ürün satışlarının transfer ile birlikte tavan seviyelerini görmesidir. Bu kapsamda özellikle lisanslı Mesut Özil forması satışları rekora ulaşmıştır. Mesut Özil transferi kulüp tarafından ilan edilir edilmez 130.000 forma satışı yapılırken forma adet fiyatı 315 TL'den satılırken transfer duyurulduğunda toplamda Forma satışından kazanılan miktar 4 Milyon 950 bin TL olarak kayıtlara geçmiştir. Bu rakam Fenerbahçe Spor Kulübünün Mesut Özil'i İstanbul'a getirdiği gün olan 24 Ocak 2020 günü 200.000 forma satış barajına ulaşarak daha önce ulaşmadığı bir rekora imza atmıştır. Sadece Mesut Özil Formasından Fenerium 6 Milyon 300 Bin Tl gelir elde ederken bu rakam her geçen gün artmaktadır. Pandemi sebebi ile maçların seyircisiz oynanması ve taraftarların forma satışlarına ilgisini azalmasına rağmen bu rakamlarda yapılan forma satışı Fenerbahçe Spor kulübünün bu transfer doğrultusun Kurumsal İmaj sürecini ne kadar iyi yönettiğinin göstergesidir. Forma satışlarının yanı sıra Fenerbahçe Spor Kulübü bu transfer çerçevesinde ' 'MESUTOL'” kampanyasına transfer sonrası Fenerbahçe Taraftarlarından Hem Yurtiçi Hem de Yurtdışı olmak üzere 150.000 sms atılmıştır.150.000 sms'in Fenerbahçe Spor Kulübüne olan getirisi ile toplamda 3 Milyon TL'dir.

Tüm bu veriler ve rakamlar incelendiğinde Fenerbahçe Spor Kulübünün Mesut Özil transferinin Kurumsal imajını tazelemesi ve güçlendirmesi adına bir süreç olduğu ortaya çıkmaktadır. Fenerbahçe Spor Kulübü bu transfer sayesinde Yurtiçi ve Yurtdışında 
milyonlarca futbol ve spor tutkunlarına ulaşarak Kulübün tanınırlık seviyesini arttırmanın yanı sıra dünya çapında olan imajını yükseltmiştir. Araştırmamızın sonucu gösteriyor ki bu transfer doğrultusunda spor sektörü kurumsal imajı geliştirmede çok yönlü bir sektör olarak karşımıza çıkmaktadır. Futbol kulüpleri gelişen dünyada transferlerini sportif yönünün yanı sıra kurumsal imaj kavramının geliştirilmesi ve etkileşimi arttırmak adına yaptığı gözlemlenmiştir.

\section{KAYNAKÇA}

Aydın M., "Uluslararası İlişkilerde Yaklaşım, Teori ve Analiz," A.Ü. SBF Dergisi (Prof. Dr. Oral Sander'e Armağan Sayısı) C. 51, No. 1-4, 71-114, 1996.

Gökçe Ateş Ç. (2016), Kurumsal İmaj Yönetimi -Kurumsal İmajın Çalışanlar Tarafindan Algılanması -Havayolu İşletmesi Örneği (Yayımlanmış Yüksek Lisans Tezi), Beykent Üniversitesi Sosyal Bilimler Enstitüsü İşletme Yönetimi Anabilim Dalı İnsan Kaynakları Ve Örgütsel Değişim Bilim Dalı, İstanbul.

Gültekin, B., Halkla İlişkilerde Etkinlik Yoluyla Imaj Oluşturulması, Ankara,2006

Internet Kaynaklarl;

https://turkish.aawsat.com/home/article/2748361/fifa-mesut-\%C3\%B6zil-fenerbah\%C3\%A7e transferini-sayfas\%C4\%B1nda

payla\%C5\%9Ft\%C4\%B1?gclid=CjwKCAjwgZuDBhBTEiwAXNofRJFYB tR6eW0SN4Ic6 yfrhacYczuW-yxreX8kCga4kdRyDEwo4QgRoCoEYQAvD_BwE Erişim Tarihi: 02.04.2021., 14:45

https://www.fotomac.com.tr/galeri/fenerbahce/fenerbahcenin-mesut-ozil-transferi-dunyabasininda/2 Erişim Tarihi: 02.04.2021., 14:45

https://tr.qaz.wiki/wiki/Kicker_(sports_magazine) Erişim Tarihi: 02.04.2021., 14:45

https://ajansspor.com/haber/adim-adim-mesut-ozil-transferi-4-ayri-ucakla-londra-seferi-

510235, Erişim Tarihi : 09.04.2021,12:44

https://skor.sozcu.com.tr/2021/01/18/fenerbahce-hisselerinde-mesut-ozil-etkisi1556740/,Erișim Tarihi : 09.04.2021,12:45

Year 5/ 2021, Volume-5, Issue-2 | WwW.ispecjournal.org 